\title{
Dividends and Problem of Separation of Ownership and Control: Theory and Evidence from French Firms
}

\author{
Hatem Ben Said ${ }^{1}$ \\ ${ }^{1}$ Higher Institute of Gabes, Tunisia \\ Correspondence: Hatem Ben Said, Higher Institute of Gabes, 6002, Tunisia. Tel: 216-93-700-039. E-mail: \\ hatbensaid@gmail.com
}

Received: April 2, 2013

Accepted: May 15, $2013 \quad$ Online Published: June 25, 2013

doi:10.5539/ijef.v5n7p162

URL: http://dx.doi.org/10.5539/ijef.v5n7p162

\begin{abstract}
This paper examines the determinants of dividends payout by focusing on the role of institutional and managerial ownership factors. It also highlights the impact of controlling shareholders on dividends payout ratios. It empirical studies the French context using a sample of 246 firms over a period of 11 years, extending from 1997 to 2007. The results indicate an inverse relationship between dividends payout and institutional ownership and support the negative effect of managerial ownership. The paper concludes, however, with the invalidity of the wealth expropriation hypothesis of minority shareholders by the controlling shareholders in both static and dynamic frameworks.
\end{abstract}

Keywords: dividends payout, managerial ownership, institutional ownership, voting rights, expropriation hypothesis

\section{Introduction}

Similar to the work of Leland and Pyle (1977), Thomson (2005), Mancinelli and Ozkan (2006), Khan (2006), Tom and Walter (2011) and Wang and David Scott (2011) this paper highlights the role of ownership structure, and the voting rights on dividend distribution. According to the agency theory of Easterbrook (1984), dividends distribution reduces managers' retrenchment behavior by encouraging firms to borrow from external investors and, therefore, be controlled by the market (Jensen and Meckling, 1976, Rozeff, 1982; Crutchley and Hansen, 1989; Goshen, 1995; Moh'd, Perry and Rimbey, 1995, Robinson, 2006). However, Zeckhauser and Pound (1990) suggest that institutional shareholders can control managers by forcing them to distribute more dividends. On the other hand, according to the "free cash flow" theory of Jensen (1986), managers are still trying to increase their managerial discretions by reducing the amounts of dividends. However, Eckbo and Verma (1994) suggest that institutional shareholders prefer to distribute "Free Cash Flow". in the form of dividends. As a result, the agency theory and "free cash flow" theory imply a significant relationship between managerial, institutional ownership and dividend yield ratios.

Unlike agency theory which interprets the agency relationship between the partners of the firm (Jensen and al, 1992), signaling theory suggests that dividends are used to convey information about future firms' earnings (Ofer and Thakor, 1987, Robinson, 2006; Bhattacharaya 1979; Bhattacharaya, 1980, Miller and Rock, 1985). However, Zeckhauser and Pound (1990) strongly support the presence of a relationship between dividend yield ratio and institutional ownership by highlighting that dividends and institutional shareholders may be considered as alternative signaling mechanisms.

Furthermore, Luciana and Aydin (2006) suggest that dividends distribution also depends on capital distribution and voting rights of majority shareholders. As a consequence, the controlling shareholders still try to expropriate the wealth of minority shareholders by reducing dividends amounts (Johnson and al, 2000; Holderness, 2000). Additionally, Bohren, Josefsen and Steen (2012) suggest that a controlling shareholder may affect dividend policy. Eckbo and Verma (1994) support a significant relationship between voting rights of a manager shareholder and dividend yield. Therefore, our paper proposes to test the impact of ownership structure and voting rights on dividend yield ratios (Thomson, 2005; Mancinelli and Ozkan, 2006). Our paper is structured as follows. In the second section, we present the main theoretical and empirical studies that support the influence of ownership structure on dividend payout ratio. The third section presents the data, to state our research hypotheses and describes our empirical methodology. The results are reported and interpreted in the fourth 
section. Section five examines sensitivity of our results by identifying the determinants of the dividend policy. The main empirical results are summarized in the last section.

\section{The Literature Review}

This section presents a summary of the main theoretical models on the impact of ownership structure on dividend yield ratios. In this regard, Shleifer and Vishny (1986) show that dividend policy is affected by the voting rights of the minority shareholders. They develop a theoretical model that introduces tax and considers that managers shareholders prefer capital gains, while institutional shareholders prefer dividends.

Schooley and Barny (1994) develop the theoretical model proposed by Rozeff (1982) which highlights the impact of managerial ownership on dividend payout under the context of agency theory (Easterbrook, 1984). Rozeff (1982) argues that dividend decision and management ownership are substitutable mechanisms to reduce transaction costs. Firms with majority shareholders distribute fewer dividends than firms with minority shareholders. In contrast, Schooley and Barny (1994) argues that the relationship between dividends and managerial ownership is non-linear (Morck, Scheifer and Vishny, 1988). They developed a model that calculates the optimal dividend yield ratio which minimizes agency and transaction costs.

Following the line of research of Townsend (1979), Stulz (1988), Hart and Moore (1994) and Hart (1995), Myers (2000) develops an inter-temporal theoretical model that examines the dividend policy as a solution of conflicts for interest between the "Insiders"and "Outsiders".

However, several empirical studies validate the relationship between dividend yield ratio and ownership structure. Accordingly, we distinguish in our literature review two main research trends; the first studies the relationship between managerial ownership and dividends, while the second line identifies the relationship between dividend policy and majority institutional shareholders. Jensen and Thomas' assumption (1992) is to study the interaction between the firm's financial policy and the managerial ownership. According to Jensen and Thomas (1992), this interaction is justified by the existence of information asymmetry between managers and outside investors. Like Peterdon and Benesh (1983) and Jalilvand and Harris (1984), Jensen and Thomas (1992) examine the relationship between debt, dividends and managerial ownership determinants. Studying a sample of 565 firms over a period of 6 years (from 1982 to 1987), the authors point to interdependence between financial decisions and managerial ownership. Specifically, managerial ownership level negatively influences debt and dividends levels.

Financial policy-wise and with reference to Jensen, Solberg and Zorn (1992), Bradley, Jarrell, Kim (1984), Amitabh Dutta (1999) examines the relationship between managerial ownership and financial decisions on a sample of American banks. As argued, the authors found a non-significant relationship between debt and managerial ownership. On the other hand, Amitabh Dutta (1999) concludes that managerial ownership negatively and significantly affects dividend yield ratio.

Following the methodology recommended by Dittmann and Maug (2007), Jouahn, Wang and Zhang (2010) examine the impact of managerial ownership on dividend policy taking into account the effect of taxation. Using a sample of 10143 American companies over a period of 13 years (from 1993 to 2005), the empirical results show a positive and statistically significant effect of managerial ownership on decision of dividend distribution policy during the years from 2003 to 2005. This relationship is not cheked at the end of 2003 when dividends are taxed at a higher rate.

In their turn, and following the works of Jensen, Solberg, and Zorn (1992), Bathala, Moon, and Rao (1994) and Chen and Steiner (1999), Crutchely and Raymond (1999) examine the joint determinants of debt, dividends, managerial ownership and institutional shareholders under agency theory. Using "Triple Least Squares" estimation method, Crutchely and Raymond (1999) conclude that the decisions of debt, dividends, managerial ownership and institutional shareholders are not jointly determined. In particular, in 1987, managerial ownership did not significantly affect debt policy and dividends of the firm and in 1993, the debt and managerial ownership weakly affected institutional ownership.

Following the papers of Brav, Graham, Harvey and Michaely (2005), Wang, and David Scott (2011) examine the impact of institutional shareholders on dividend policy of Chinese companies. First, the authors identified the factors explaining dividend ratios in a dynamic framework. In a second step, Wang, and David Scott (2011) introduced in their models the impact of outside investors' ownership. Using 1024 firms listed in the Chinese market over a period of 11 years (from 1998 to 2008) taken from the "CSMAR" database, the authors indicate that earnings volatility significantly affects dividend yield ratios (Glen, Karmokolias, Miller and Shah, 1995). In addition, the results show also that the decision to distribute dividends is positively related with the decision of 
the previous year. Similarly, according to the agency theory, the authors conclude that institutional ownership positively and significantly affects the decision to distribute dividends.

\section{Data and Methodology}

\subsection{Sample Selection}

Our methodology tests the relationship between dividend yield ratio and ownership structure using a sample of 246 French listed firms over a period of 11 years, from 1997 to 2007, taken from "MERGENTONLINE", and "DATASTREAM" databases. Data on ownership structure are taken from the annual reports available in the "MERGENTONLINE" Database.

\subsection{Models}

Fama and Babiak (1968) tested a number of different models of forecasting dividends ratios and reported that the partial adjustment model of Lintner (1956) generates the most accurate results. Benartzi, Michaely, and Thaler (1997) found that the model of Lintner (1956) is the best model that describes dividend policy. Therefore, and following the works of McDonald and Jacquillat Nussenbaum (1975), Shevlin (1982), Partington (1984), Leithner and Zimmerman (1993), Dewenter and Warther (1998), Robinson (2006) and Wang and David Scott (2011), we use the full adjustment model, the partial adjustment model, Waud and Earnings trend model formulated as follows as suggested by Short and al (2002), to describe the relationship between dividends and ownership structure:

$$
\begin{gathered}
\Delta D=f\left(\Delta E, \Delta E^{*} \text { inst }, \Delta E^{*} M D u m\right) \\
\Delta D=f\left(E, E^{*} i N S T, E^{*} M D u m, D_{t-1}\right) \\
\Delta D=f\left(E, E^{*} \text { Inst, } E^{*} M D u m, D_{t-1}, D_{t-2}\right) \\
\Delta D=f\left(E_{t}, E_{t-1}, E_{t-1}^{*} \text { Inst, } E_{t-1} * M D u m, D_{t-1}\right)
\end{gathered}
$$

Where " $\mathrm{D}$ " denotes amount of dividends distributed, “ $\Delta D$ ”, changes in dividends, and " $\mathrm{E}$ ", earnings. However, the theory examines the impact of controlling shareholders on dividend yield ratios (Zuoping, 2011). In other words, can we assume that the separating ownership and control affects the dividend policy? A significant number of researchers have addressed to address this problem (Luciana and Aydin, 2006; Dickens, Casey and Newman, 2003). We usually find two opposing approaches: a static approach that identifies the determinants of dividend yield ratios and a dynamic approach. However, following the methodologies recommended by Luciana and Aydin (2006), Dickens, Casey and Newman (2003), Kim and Liow (2010) and with reference to the above discussion of works of Lintner (1956) and Fama and Babiak (1968) which assume firms to follow a stable dividend policy according to the following TOBIT regressions (Luciana and Aydin, 2006):

$$
\begin{aligned}
& P A Y_{1 i, t}=\alpha_{0}+\alpha_{1} \text { SIZE }_{i, t}+\alpha_{2} \text { LEVIER }_{i, t}+\alpha_{3} \text { MTB }_{i, t}+\alpha_{4} \text { Voting }_{i, t}-\text { Rights }_{i, t}+\varepsilon_{i t} \\
& P A Y_{1 i, t}=\alpha_{0}+\alpha_{1} \text { SIZE }_{i, t}+\alpha_{2} \text { LEVIER }_{i, t}+\alpha_{3} \text { MTB }_{i, t}+\alpha_{4} \text { Voting }_{i, t}-\text { Rights }_{i, t}+P A Y_{1 i, t-1}+\varepsilon_{i t} \\
& P A Y_{1 i, t}=\alpha_{0}+\alpha_{1} \text { SIZE }_{i, t}+\alpha_{2} \text { LEVIER }_{i, t}+\alpha_{3} \text { MTB }_{i, t}+\alpha_{4} \text { Voting }_{i, t} \text { Rights All }_{i, t}+\varepsilon_{i t} \\
& P A Y_{1 i, t}=\alpha_{0}+\alpha_{1} \text { SIZE }_{i, t}+\alpha_{2} \text { LEVIER }_{i, t}+\alpha_{3} \text { MTB }_{i, t}+\alpha_{4} \text { Voting }_{i, t} \text { IO1 }_{i, t}+\varepsilon_{i t} \\
& P A Y_{1 i, t}=\alpha_{0}+\alpha_{1} \text { SIZE }_{i, t}+\alpha_{2} \text { LEVIER }_{i, t}+\alpha_{3} \text { MTB }_{i, t}+\alpha_{4} \text { Voting }_{i, t} \text { OC1 }_{i, t}+\varepsilon_{i t} \\
& P A Y_{1 i, t}=\alpha_{0}+\alpha_{1} S_{Z I Z E_{i, t}}+\alpha_{2} \text { LEVIER }_{i, t}+\alpha_{3} \text { MTB }_{i, t}+\alpha_{4} A L F A_{i, t}+\varepsilon_{i t}
\end{aligned}
$$

In a third step, we measure the impact of monitoring power of the other shareholders (Du and Dai, 2004) on the dividends yield ratios in a static framework, using the following system of equations:

$$
\begin{aligned}
& P A Y_{1 i, t}=\alpha_{0}+\alpha_{1} \text { SIZE }_{i, t}+\alpha_{2} \text { LEVERAGE }_{i, t}+\alpha_{3} \text { MTB }_{i, t}+\alpha_{4} \text { Voting }_{i, t}-\text { Rights }_{i, t}+\varepsilon_{i t} \\
& \text { PAY }_{1 i, t}=\alpha_{0}+\alpha_{1} \text { SIZE }_{i, t}+\alpha_{2} \text { LEVERAGE }_{i, t}+\alpha_{3} \text { MTB }_{i, t}+\alpha_{4} \text { Voting }_{i, t}-\text { Rights }_{i, t}+2 \text { Larg }_{\text {e Shareholder }}+\varepsilon_{i t} \\
& P A Y_{1 i, t}=\alpha_{0}+\alpha_{1} \text { SIZE }_{i, t}+\alpha_{2} \text { LEVERAGE }_{i, t}+\alpha_{3} \text { MTB }_{i, t}+\alpha_{4} \text { Voting }_{i, t}-\text { Rights1 }_{i, t}+2 L \operatorname{Larg} \text { Shareholder }_{i t}+P A Y_{1, t-1}+\varepsilon_{i t} \\
& P A Y_{1 i, t}=\alpha_{0}+\alpha_{1} \text { SIZE }_{i, t}+\alpha_{2} \text { LEVERAGE }_{i, t}+\alpha_{3} \text { MTB }_{i, t}+\alpha_{4} \text { Voting }_{i, t}-\text { Rights }_{i, t}+\text { Other L } \arg \text { e Shareholder }{ }_{i t}+\varepsilon_{i t} \\
& P A Y_{1 i, t}=\alpha_{0}+\alpha_{1} \text { SIZE }_{i, t}+\alpha_{2} \text { LEVERAGE }_{i, t}+\alpha_{3} \text { MTB }_{i, t}+\alpha_{4} \text { Voting }_{i, t}-\text { Rights }_{i, t}+\text { Voting Rights All }{ }_{i t}+\varepsilon_{i t}
\end{aligned}
$$

Following the methodology supported by Fama and French (2001), DeAngelo, DeAngelo and Stulz (2004), 
Denis and Osobov (2007), Vineeta (2011) and Darren Henry (2011) we use regression models "LOGIT" to examine the influence of different shareholders on the decision to distribute dividends. The last step in our analysis will provide an opportunity to study the sensitivity of our results using a "LOGIT" regression analysis, which provides empirical determinants of the probability of firms to pay dividends. It should be noted that firms choose to pay or not to pay dividends each year. It is therefore necessary to check whether our models affect the dividend decision itself, rather than the level of dividends using a binary model called "LOGIT" which is written as follows;

$$
\begin{aligned}
& \text { DIVPAY } Y_{i, t}=\alpha_{0}+\alpha_{1} \operatorname{SIZE}_{i, t}+\alpha_{2} \text { LEVERAGE }_{i, t}+\alpha_{3} \text { MTB }_{i, t}+\alpha_{4} \operatorname{Vot}_{\text {Rig }} 1_{i, t}+\varepsilon_{i, t} \\
& \operatorname{DIVPAY}_{i, t}=\alpha_{0}+\alpha_{1} \text { SIZE }_{i, t}+\alpha_{2} \text { LEVERAGE }_{i, t}+\alpha_{3} \text { MTB }_{i, t}+\alpha_{4} \text { Voting Rights All }_{i, t}+\varepsilon_{i, t} \\
& \text { DIVPAY } Y_{i, t}=\alpha_{0}+\alpha_{1} \text { SIZE }_{i, t}+\alpha_{2} \text { LEVERAGE }_{i, t}+\alpha_{3} \text { MTB }_{i, t}+\alpha_{4} \text { Voting Rights IO1 }_{i, t}+\varepsilon_{i, t} \\
& \text { DIVPAY }_{i, t}=\alpha_{0}+\alpha_{1} \text { SIZE }_{i, t}+\alpha_{2} \text { LEVERAGE }_{i, t}+\alpha_{3} \text { MTB }_{i, t}+\alpha_{4} \text { Voting Rights OC }_{i, t}+\varepsilon_{i, t} \\
& \text { DIVPAY } Y_{i, t}=\alpha_{0}+\alpha_{1} S_{\text {SIEE }}+\alpha_{2}{ }_{\text {LEVERAGE }}+\alpha_{3} M T B_{i, t}+\alpha_{4} A L F A_{i, t}+\varepsilon_{i, t} \\
& D_{\text {DVPAY }}=\alpha_{0, t}+\alpha_{1} \text { SIZE }_{i, t}+\alpha_{2} \text { LEVERAGE }_{i, t}+\alpha_{3} \text { MTB }_{i, t}+\alpha_{4} 2 \text { LargeShareholder } i_{i, t}+\varepsilon_{i, t} \\
& \text { DIVPAY } Y_{i, t}=\alpha_{0}+\alpha_{1} \text { SIZE }_{i, t}+\alpha_{2} \text { LEVERAGE }_{i, t}+\alpha_{3} M T B_{i, t} \\
& +\alpha_{4} \text { 2Other Large Shareholder }{ }_{i, t}+\varepsilon_{i, t}
\end{aligned}
$$

Finally, following Goergen, Renneboog and Silva (2005), we test the joint effect of ownership structure and earnings loss on the decision to distribute dividends according to the following formulation;

$$
\begin{aligned}
& \text { DIVPAY } Y_{i, t}=\alpha_{0}+\alpha_{1} \text { SIZE }_{i, t}+\alpha_{2} \text { LEVERAGE }_{i, t}+\alpha_{3} \text { MTB }_{i, t}+\alpha_{4} \operatorname{NLOSS}_{i t}+\operatorname{NLOSS}_{i t} * E B O 1_{i t}+\varepsilon_{i t} \\
& \operatorname{DIVPAY}_{i, t}=\alpha_{0}+\alpha_{1} \text { SIZE }_{i, t}+\alpha_{2} \text { LEVERAGE }_{i, t}+\alpha_{3} \text { MTB }_{i, t}+\alpha_{4} \operatorname{NLOSS}_{i t}+N L O S S_{i t} * E B O 2_{i t}+\varepsilon_{i t} \\
& D_{V P A} Y_{i, t}=\alpha_{0}+\alpha_{1} \text { SIZE }_{i, t}+\alpha_{2} \text { LEVERAGE }_{i, t}+\alpha_{3} \text { MTB }_{i, t}+\alpha_{4} \text { NLOSS }_{i t}+\operatorname{NLOSS}_{i t} * I O 1_{i t}+\varepsilon_{i t} \\
& D_{\text {IVPAY }}{ }_{i, t}=\alpha_{0}+\alpha_{1} \text { SIZE }_{i, t}+\alpha_{2} \text { LEVERAGE }_{i, t}+\alpha_{3} \text { MTB }_{i, t}+\alpha_{4} \operatorname{NLOSS}_{i t}+\operatorname{NLOSS}_{i t} * I O 2_{i t}+\varepsilon_{i t} \\
& \text { DIVPAY } Y_{i, t}=\alpha_{0}+\alpha_{1} \text { SIZE }_{i, t}+\alpha_{2} \text { LEVERAGE }_{i, t}+\alpha_{3} \text { MTB }_{i, t}+\alpha_{4} \operatorname{NLOSS}_{i t}+N L O S S_{i t} * O W 1_{i t}+\varepsilon_{i t} \\
& \text { DIVPAY } Y_{i, t}=\alpha_{0}+\alpha_{1} \text { SIZE }_{i, t}+\alpha_{2} \text { LEVERAGE }_{i, t}+\alpha_{3} \text { MTB }_{i, t}+\alpha_{4} \operatorname{NLOSS}_{i t}+N L O S S_{i t} * O W 2_{i t}+\varepsilon_{i t}
\end{aligned}
$$

\subsection{Variables Choice and Hypothesis}

The study of the relationship between dividends and ownership structure requires the use of different variables.

\subsubsection{Variables Choice}

\section{The dependant variable}

"Dividends", following the methodology suggested by Christian, Andrew, Marc and Renneboog (2011) who used partial adjustment models to describe the dividend policy in the context of German, we use as a measure of dividends total cash dividends paid each year.

"Dividends yield ratio" the empirical literature proposes several measures of dividends yield ratios. The first two ratios are measured by the total cash dividends paid each year divided, respectively, by net income (Kimie and Pascal, 2011) and market capitalization. In order to examine sensitivity of our empirical results, we use the ratios of the total cash dividends paid to cash flow and dividends to turnover (La porta, Lopez, Shleifer and Vishny, 2000).

\section{The independent variables}

It should be noted that in our estimation and in order to reduce the potential of a possible endogeneity problem, we use lagged explanatory control variables.

"Institutional ownership" according to Jensen and Al (1992), ownership structure could be related with dividend yield ratio. Therefore, institutional ownership is approximated by the percentage of equity held by external investors higher or equal to $5 \%$. The measure of institutional ownership is made by two different methods. The first measure is a dummy variable which takes 1 if an institutional shareholder owns more than $5 \%$ is present and zero otherwise. The second method measures sensitivity of our results by using dummy variable that takes 1 if the largest institutional shareholder owns $5 \%$ or more of equity and zero otherwise......we document 
a positive relationship between dividends and institutional ownership (Szilagyi and Renneboog, 2007).

"Management ownership" we approximate managerial ownership by the share of capital held by members of the Board of Directors. We use, also, a dummy variable that takes 1 if management ownership is higher or more than $5 \%$ of equity and zero otherwise. The other measure of insider ownership uses a second dummy variable, "MDum1" which takes 1 if the largest manager shareholder "IO1" owns more than 5\% and zero otherwise. Jensen (1986) suggests that managers follow an entrenchment behavior by reducing the amount of dividends distributed. We expect a negative sign for management ownership on dividend yield ratio.

"Voting rights of controlling shareholder and other shareholders" Faccio and Al (2001) argue that dividend rates are affected by voting rights of shareholders. In addition, Chen and al (2009) suggest that majority shareholders prefer high dividend yield. Thus, two dummy variables are used as measures of voting rights. The first dummy variable (2- Large Shareholder) takes a value of 1 when the voting rights of the second largest shareholder equals or is greater than $5 \%$ and zero otherwise. The second dummy variable (Other-Large Shareholders) takes the value of 1 if the voting rights of all shareholders with equity higher than $2 \%$ other than the controlling shareholder is greater than $5 \%$ and zero otherwise.

"Firm size" according to the work of Barclay, Smith and Watts (1995), and Ross, Michael and Joseph (2003), we approximate firm size by the natural logarithm of sales. The larger the firm is, the weaker bankruptcy probability is and the more the firm distributes dividends (Fama and French, 2001). We assume that this variable positively affects dividend yield.

"Leverage" leverage is defined as total debt over total assets. We expect a negative relationship between debt and dividend yield ratios. According to "Free cash Flow" theory of Jensen (1986), debt and dividends can be considered as substitutable mechanisms to control managers' opportunistic behavior. We assume that this variable negatively affects dividend yield.

“Market To Book ratio" similar to Barclay, Smith and Watts (1995), we define Market To Book ratio as market capitalization over the book value of equity. Fama and French (2001) suggest that higher growth opportunities require a higher cash flow. In doing so, managers retain the profits of the firm and do not distribute dividends. A negative relationship between growth opportunity and dividend yield is expected (La Porta, Lopez, Shleifer and Vishny, 2000). However, La Porta, Lopez, Shleifer and Vishny (2000) suggest that in the case of a high Market To Book ratio, firms can distribute more dividends in order to send a good signal to external investors and control managers' opportunistic behavior. In this case, a positive relationship is expected between growth opportunities and dividend yield.

"interaction term" in order to test the influence of the interaction between capital concentration and earnings of the firm on the dividend policy, we introduce into our model, and following the methodology recommended by Georgen, Renneboog and Silva (2005), an interaction term defined as, "WHLOSS $S_{i, t}=W_{i, t} * N I L O S S_{i, t}$ ”, with " $W H_{i, t}$ " a dummy variable that takes 1 if there is no controlling shareholder with at least a $25 \%$ (50\%) of equity and zero otherwise, "NILOSS ${ }_{i, t}$ " a dummy variable that takes 1 in case of earnings loss and zero otherwise.

\subsubsection{Hypothesis of Our Research}

The formulation of our research hypotheses refers to agency and signaling theories. In the perspective of agency theory, institutions can ask for high levels of dividend in order to stimulate managers to go to the financial market to finance their projects and therefore be subject to external control markets. According to the "Free Cash Flow" theory institutions may not prefer to keep "Free Cash Flow". "Free Cash Flow" and the agency theories suggest, therefore, a positive relationship between dividends and institutional shareholders. In contrast, signaling theory suggests that dividends and institutions can be substitutes to signaling mechanisms. The tests of the influence of institutional ownership on dividends ratios are limited. Eckbo and Verma (1994) conclude a positive relationship between dividend yield and managers' voting rights. Similarly, Moh'd, Perry and Rimbey (1995) and Bhagat and Jefferis (2002) argue that share of capital held by external investors positively affects dividends ratios. Furthermore, Zeckhauser and Pound (1990) did not find conclude a significant influence of institutional ownership on dividends yield ratios. Referring to agency theory, we develop our first hypothesis.

Agency theory Hypothesis 1: there is a positive relationship between changes in dividends and institutional ownership. 
Table 1. Measures of variables and predicted signs

\begin{tabular}{|c|c|c|c|}
\hline $\begin{array}{l}\text { variable } \\
\text { dividends }\end{array}$ & $\begin{array}{l}\text { Name } \\
\text { D }\end{array}$ & $\begin{array}{l}\text { Measure } \\
\text { Dividendes totales }\end{array}$ & $\begin{array}{l}\text { Predicted Sign } \\
\text { Dépendant variable }\end{array}$ \\
\hline Dividend payout & PAYOUT1 & PAYOUT1 $=\frac{\text { Dividendes }}{R \text { 䦔ulatts Nets }}$ & Dépendant variable \\
\hline Dividend payout & PAYOUT2 & PAYOUT2 $=\frac{\text { Dividendes }}{\text { Capitalisation Boursi 開e }}$ & Dépendant variable \\
\hline Dividend payout & PAYOUT3 & PAYOUT3 $=\frac{\text { Dividendes }}{\text { Cash Flow }}$ & Dépendant variable \\
\hline Dividend payout & PAYOUT4 & PAYOUT3 $=\frac{\text { Dividendes }}{\text { Chiffre d'affaires }}$ & Dépendant variable \\
\hline Institutional ownership & INST & Inst $=\left\{\begin{array}{cc}1 & \text { si Inst }>0,05 \\
0 & \sin \text { on }\end{array}\right.$ & + \\
\hline Institutional ownership & INST1 & Inst $1=\left\{\begin{array}{cc}1 & \text { si Inst } 1>0,05 \\
0 & \text { sin } \text { on }\end{array}\right.$ & + \\
\hline Management ownership & MDum & $M D u m=\left\{\begin{array}{cc}1 & \text { si } \mathrm{CEO}>0,05 \\
0 & \text { sin } o n\end{array}\right.$ & - \\
\hline Management ownership & MDum2 & $M D u m 1=\left\{\begin{array}{cc}1 & \text { si } I \mathrm{O} 1>0,05 \\
0 & \text { sin on }\end{array}\right.$ & - \\
\hline $\begin{array}{l}\text { Voting Rights of the largest } \\
\text { shareholder }\end{array}$ & Voting-Rights & DDVOW1 & - \\
\hline $\begin{array}{l}\text { Voting Rights of the largest } \\
\text { shareholder manager }\end{array}$ & $\begin{array}{l}\text { Voting-Rights } \\
\text { IO1 }\end{array}$ & DDVIO1 & - \\
\hline $\begin{array}{l}\text { Voting Rights of the largest } \\
\text { Institutional shareholder }\end{array}$ & $\begin{array}{l}\text { Voting-Rights } \\
\text { OC1 }\end{array}$ & DDVOC1 & - \\
\hline $\begin{array}{l}\text { Voting Rights of all } \\
\text { shareholder }\end{array}$ & $\begin{array}{l}\text { Voting Rights } \\
\text { All }\end{array}$ & Voting - Rights - All $=\sum_{i=1}^{n} D D V_{i}$ & - \\
\hline Degré of control & ALFA & $A L F A=\frac{P(n)}{\sqrt{H-P(n)^{2}}}$ & - \\
\hline $\begin{array}{l}\text { Voting Rights of the second } \\
\text { largest shareholders }\end{array}$ & 2LargeShare & 2 Large Shareholder $=\left\{\begin{array}{cc}1 & \text { si } \mathrm{DDV}_{2}>0,05 \\
0 & \sin \text { on }\end{array}\right.$ & - \\
\hline $\begin{array}{l}\text { Voting Rights of } \\
\text { other shareholders }\end{array}$ & OtherLarge & OtherLargShareholds $=\left\{\begin{array}{cc}1 & \text { siDDY }>0,05 \text { aved }=1-n \\
0 & \text { sinon }\end{array}\right.$ & - \\
\hline Firm size & SIZE & $\mathrm{SIZE}=\operatorname{Ln}(\mathrm{CA})$ & + \\
\hline Leverage & LEVIER & $L E V I E R=\frac{D L T+D C T}{T O T A L A C T I F}$ & - \\
\hline Market To Book Ratio & MTB & $M T B=\frac{\text { CapitalisationBoursiere }}{\text { Capitaux } \operatorname{Pr} \text { opres }}$ & + \\
\hline
\end{tabular}

We can also approximate agency costs by the share of capital held by managers. This measure has been widely used in the literature (Rozeff, 19682; Jensen and Thomas, 1992). Under agency theory, Jensen and Meckling (1976) suggest that management ownership reduces agency costs associated with equity capital. Therefore, the higher management ownership is, the less the need to use dividends to mitigate agency costs. Therefore, managers are expected to exert a negative impact on dividends yield ratios. Then, our second hypothesis can be stated as follows:

Hypothesis 2: there is a negative relationship between changes in dividends and management ownership.

Our research studies the relationship between dividends and voting rights, while the controlling shareholders expropriate the wealth of minority shareholders. Luciana and Aydin (2006) argue that we should expect a negative relationship between shareholders' voting rights and dividend yield ratios (Shleifer and Vishny, 1997; Facio and al, 2000; Holderness, 2003). This negative relationship is suggested by agency theory discussed above. 
Hypothesis of expropriation of shareholder wealth: there is a negative relationship between dividend yield and monitoring power of controlling shareholders.

\section{Empirical Results}

\subsection{Descriptive Statistics}

Table 2 below reports the descriptive statistics for the dummy variables. During the period 1997 to 2003, the mean dividend payment is growing, but with a decrease in the years 1997, 1999 and 2003. During 2003, the mean dividend payment is growing again until 2007. The mean earnings, while increasing in the period from 1997 to 2000, decreased in 2001, and then it increased from 2002 to 2007. Changes in earnings and dividends indicate that firms try to keep a stable level of dividends. Institutional ownership concentration remains constant and equal to $100 \%$ during the study period, except for 2005 , which is equal to $99.59 \%$. However, when we considered largest institutional shareholder as a dummy variable, institutional ownership concentration increased significantly from 1997 to 2002 , reaching a level of $85.36 \%$. At the beginning of 2003, the concentration starts to decrease, reaching a value of $48.37 \%$. Regarding the management ownership, it stabilized in the years 1997 and 1998 to a value of $70,73 \%$ and decreased in 1999 , reaching a value of $69.91 \%$. During the year 2000 , concentration increased and reached a value of $72.76 \%$. At this time, the concentration becomes increasing and reached a value of $74.39 \%$ in 2003 , and then decreased again to $69.91 \%$ in 2007 . When considering the largest manager shareholder, we document a low volatility of capital concentration.

However, Table 3 reports the mean values of other variables for each activity sector. Indeed, the table shows that in the case of dividend yield measured by "PAYOUT1", the firm distributes in average $17.77 \%$ of its earnings as dividends to shareholders. However, in the case of dividend yield ratios measured, respectively, by "PAYOUT2", "PAYOUT3" and "PAYOUT4" we document a distribution rate of $1.79 \%, 15.40 \%$ and $2.20 \%$ (Michel, 1979). For the activity sectors, we find a mean dividend payment around $9.99 \%$ in the oil sector. The largest shareholder holds, on average, $56.51 \%$ of the voting rights, with a minimum of $2.85 \%$ and a maximum of $100 \%$. The percentage of shareholders' voting rights is, on average, $98.01 \%$.

Table 2. Descriptive statistics of Dummy variables

\begin{tabular}{|c|c|c|c|c|c|c|c|c|c|c|c|c|}
\hline & \multicolumn{2}{|c|}{ Dividends (in TND) } & \multicolumn{2}{|c|}{ Net Earnings (in TND) } & \multicolumn{2}{|c|}{ INST } & \multicolumn{2}{|c|}{ INST1 } & \multicolumn{2}{|c|}{ MDUM } & \multicolumn{2}{|c|}{ MDUM1 } \\
\hline & moyenne & déviation & moyenne & déviation & $\mathbf{n}$ & $\%$ & $\mathbf{n}$ & $\%$ & $\mathbf{n}$ & $\%$ & $\mathbf{n}$ & $\%$ \\
\hline 1997 & 75200000 & 326000000 & -13500000 & 1470000000 & 246 & $100 \%$ & 86 & 34,95 & 174 & 70,73 & 171 & 69,51 \\
\hline 1998 & 38100000 & 151000000 & 3756927 & 1470000000 & 246 & $100 \%$ & 144 & 58,53 & 174 & 70,73 & 170 & 69,10 \\
\hline 1999 & 40200000 & 162000000 & 14500000 & 148000000 & 246 & $100 \%$ & 180 & 73,17 & 172 & 69,91 & 169 & 68,69 \\
\hline 2000 & 4600000 & 19000000 & 53600000 & 1550000000 & 246 & $100 \%$ & 202 & 82,11 & 179 & 72,76 & 172 & 69,91 \\
\hline 2001 & 65400000 & 247000000 & 31100000 & 1580000000 & 246 & $100 \%$ & 205 & 83,33 & 180 & 73,17 & 170 & 69,10 \\
\hline 2002 & 65600000 & 236000000 & 62900000 & 1550000000 & 246 & $100 \%$ & 210 & 85,36 & 183 & 74,39 & 176 & 71,54 \\
\hline 2003 & 63200000 & 230000000 & 127000000 & 625000000 & 246 & $100 \%$ & 208 & 84,55 & 183 & 74,39 & 172 & 69,91 \\
\hline 2004 & 82900000 & 351000000 & 173000000 & 822000000 & 246 & $100 \%$ & 207 & 84,14 & 180 & 73,17 & 172 & 69,91 \\
\hline 2005 & 99300000 & 385000000 & 268000000 & 1060000000 & 245 & $99,59 \%$ & 202 & 82,11 & 173 & 70,32 & 164 & 66,66 \\
\hline 2006 & 131000000 & 499000000 & 313000000 & 1100000000 & 246 & $100 \%$ & 193 & 78,45 & 174 & 70,73 & 169 & 68,69 \\
\hline 2007 & 159000000 & 600000000 & 342000000 & 1270000000 & 246 & $100 \%$ & 119 & 48,37 & 172 & 69,91 & 165 & 67,073 \\
\hline 1997-2007 & 75200000 & 326000000 & 125000000 & 1310000000 & & & & & & & & \\
\hline
\end{tabular}

Table 3. Descriptive statistics of other variables

\begin{tabular}{lllllll}
\hline & Oil & Industrie & Transport & Trade & Service & Total \\
\hline Paout1 & 0,209 & 0,177 & 0,180 & 0,188 & 0,157 & 0,177 \\
Paout2 & 0,0193 & 0,0210 & 0,0248 & 0,0147 & 0,0105 & 0,0179 \\
Paout3 & 0,153 & 0,178 & 0,106 & 0,149 & 0,125 & 0,154 \\
Paout4 & 0,0184 & 0,0226 & 0,0266 & 0,0115 & 0,0286 & 0,0220 \\
Ddvio1 & 0,279 & 0,352 & 0,170 & 0,324 & 0,397 & 0,339 \\
Ddvoc1 & 0,452 & 0,414 & 0,555 & 0,435 & 0,407 & 0,430 \\
alfa & 0,958 & 0,908 & 0,982 & 0,922 & 0,918 & 0,921 \\
Size & 20,561 & 19,722 & 21,630 & 19,586 & 19,222 & 19,805 \\
Leverage & 0,431 & 0,461 & 0,491 & 0,529 & 0,507 & 0,482 \\
MTB & 3,021 & 2,897 & 3,159 & 3,383 & 4,192 & 3,267 \\
Voting Rights 1 & 0,652 & 0,539 & 0,650 & 0,589 & 0,546 & 0,565 \\
Voting Rights All & 0,966 & 0,981 & 0,971 & 0,979 & 0,984 & 0,980 \\
\hline
\end{tabular}




\subsection{Impact of Ownership Structure on Dividend Yield Ratios}

Table 4 reports the results of applying the models described above. For each model, we report the results of three specifications for the alternative measures of the largest institutional shareholder and manager already described.

According to the results of the regressions for all four models indicate a convincing explanatory power for the models. The results of the full adjustment model (MAT) show that the coefficients of the variables " $\mathrm{E}_{\mathrm{it}}-\mathrm{E}_{\mathrm{it}-\mathrm{l}}$ " et " $\left(\mathrm{E}_{\mathrm{it}}-\mathrm{E}_{\mathrm{it}-1}\right)^{*}$ Inst" are respectively positive and negative, but not statistically significant (specification "MAT1"). Therefore, in the case of French, institutional shareholders do not affect the distribution of dividends. In contrast, referring to the results of Kevin Heibatolla and Zhou (2012), the sign of the variable " $\left(E_{i t}-E_{i t-1}\right) \operatorname{Inst1}$ " is negative and statistically significant at the $1 \%$ level (specification "MAT2"). This result indicates that the largest institutional shareholder can be considered as a signaling mechanism to substitute dividend distribution, which confirms the sign as suggested by signaling theory. In addition, the positive and significant coefficients of the variables " $\left(E_{i t}-E_{i t-1}\right) M D u m$ ” and " $\left(E_{i t}-E_{i t-1}\right) M D u m 1$ " does not support the hypothesis of a negative relationship between management ownership and dividend payout ratio ("MAT2" et "MAT3"). This result suggests that management ownership and dividends are complementary mechanisms to reduce agency costs. In other words, if the manager has a share capital of the company, we document, therefore, an alignment effect of interests between manager and shareholder and dividends distribution in order to send a good signal to external investors about its behavior and the performance of the firm.

Regarding the partial adjustment model (PAM), we found that the coefficient of the variable " $\mathrm{D}_{\mathrm{t}-1}$ " is negative and statistically significant while the coefficient of the variable " $E_{t}$ " is positive and statistically significant for the second alternative ("MAP2"). Contrary to our research hypothesis, the coefficient on the variable " $\mathrm{E}_{\mathrm{t}}^{*}$ Inst" is negative and statistically significant when we consider the largest shareholder as a proxy for institutional ownership ("MAP2"). This result suggests that institutional shareholders encourage managers to distribute less dividends. However, it seems that the relationship between management ownership and dividend payout ratios is negative and statistically significant ("MAP2" et "MP3"), which confirms our third hypothesis.

The results of Waud model "WM" confirm our hypothesis. The coefficient of the variable " $D_{t-1}$ " is negative and statistically significant, while the coefficient of variable " $\mathrm{D}_{\mathrm{t}-2}$ " is not statistically significant ("MW 1 "). The coefficient of the variable " $\mathrm{E}_{\mathrm{t}}$ " is positive and statistically significant when we consider the controlling shareholder, and the coefficient " $\mathrm{cdr}_{1}$ " of the variable " $\mathrm{E}_{\mathrm{t}}{ }^{*}$ Inst" is negative and statistically significant for the second alternative ("MW2"). This result rejects our second research hypothesis. In contrast, the negative and statistically significant impact of management ownership, measured by the largest shareholder manager for three specifications ("MW1", "MW2" and "MW3") confirms our second hypothesis.

Finally, the results of the Earnings trend model "ETM" indicate that the variable " $\mathrm{D}_{\mathrm{t}-1}$ " significantly and negatively affects changes in dividends. Earnings " $\mathrm{E}_{\mathrm{t}}$ " positively and significantly affects changes in dividends (specifications "ETM1", "ETM2" and "ETM3"). The coefficient of the variable " $\mathrm{E}_{\mathrm{t}-\mathrm{l}}$ " is positive and statistically significant at the $1 \%$ level, when considering the largest institutional shareholder ("ETM2"). However, the variable " $\mathrm{E}_{\mathrm{t}-1}$ *MDum" is negatively and significantly affects changes in dividends ("ETM1" and "ETM2"). On the other hand, the effect of the variable " $\mathrm{E}_{\mathrm{t}-1}{ }^{*} \mathrm{Inst}_{1}$ " on changes of dividends is negative and statistically significant for the second alternative ("ETM2").

Overall, the results of the four models are conclusive. They reject the hypothesis of a positive relationship between dividend policy and institutional ownership and support the negative relationship between dividend policy and management ownership. 
Table 4. Relationship between dividends and ownership structure

\begin{tabular}{|c|c|c|c|c|c|c|c|c|c|c|c|c|}
\hline & Full & $\begin{array}{c}\text { adjustment } \\
\text { (MAT) }\end{array}$ & model & Partial & $\begin{array}{l}\text { adjustment } \\
\text { (MAP) }\end{array}$ & model & & $\begin{array}{l}\text { ud model (1 } \\
(\mathrm{MW})\end{array}$ & 966) & & $\begin{array}{l}\text { "ETM" mod } \\
\text { (ETM) }\end{array}$ & \\
\hline & MAT1 & MAT2 & MAT3 & MAP1 & MAP2 & MAP3 & MW1 & MW2 & MW3 & ETM1 & ETM2 & ETM3 \\
\hline$E_{i t}-E_{i t-1}$ & 0,131 & 0,0195 & 0,1300 & & & & & & & & & \\
\hline$\left(E_{i t}-E_{i t-1}\right) I n s t$ & $-0,159$ & & $-0,1498$ & & & & & & & & & \\
\hline$\left(E_{i t}-E_{i t-1}\right) \operatorname{Ins} \boldsymbol{A}$ & & $-0,0504^{* * *}$ & & & & & & & & & & \\
\hline$\left(E_{i t}-E_{i t-1}\right) M D u m$ & $0,780^{* * *}$ & $0,0794^{* * *}$ & & & & & & & & & & \\
\hline$\left(E_{i t}-E_{i t-1}\right) M D u m 1$ & & & $0,0692^{* * *}$ & & & & & & & & & \\
\hline$E_{i t}$ & & & & 0,0809 & $0,0841^{* * *}$ & 0,0794 & 0,0840 & $0,110^{* * *}$ & 0,0801 & $0,0192^{* * *}$ & $0,01936^{* * *}$ & $0,0147^{* * *}$ \\
\hline$E_{i t} *$ Inst & & & & $-0,0321$ & & $-0,0343$ & $-0,0227$ & & $-0,0294$ & & & \\
\hline$E_{i t} * I n s t 1$ & & & & & $-0,0378^{* * *}$ & & & $-0,0537^{* * *}$ & & & & \\
\hline$E_{i t} * M D u m$ & & & & $-0,0169^{* * *}$ & $-0,0146^{* * *}$ & & $-0,0304^{* * *}$ & $-0,0255^{* * *}$ & & & & \\
\hline$E_{i t} * M D u m 1$ & & & & & & $-0,0147^{* * *}$ & & & $-0,0213^{* * *}$ & & & \\
\hline$D_{i t-1}$ & & & & $-0,0574^{* * *}$ & $-0,0725^{* * *}$ & $-0,0532^{* * *}$ & $-0,118^{* * *}$ & $-0,1380^{* * *}$ & $-0,1047^{* * *}$ & $-0,0998^{* * *}$ & $-0,1079^{* * *}$ & $-0,0928^{* * *}$ \\
\hline$D_{i t-2}$ & & & & & & & 0,0389 & 0,0299 & 0,0338 & & & \\
\hline$E_{i t-1}$ & & & & & & & & & & 0,0511 & $0,0673^{* * *}$ & 0,0520 \\
\hline$E_{i t-1} *$ Inst & & & & & & & & & & $-0,00354$ & & $-0,00763$ \\
\hline$E_{i t-1} * I n s t 1$ & & & & & & & & & & & $-0,0215^{* * *}$ & \\
\hline$E_{i t-1} * M D u m$ & & & & & & & & & & $-0,0277^{* * *}$ & $-0,0267^{* * *}$ & \\
\hline$E_{i t-1} * M D u m$ & & & & & & & & & & & & $-0,0205^{* * *}$ \\
\hline$R^{2}$ & $4.19 \%$ & $4.47 \%$ & $2.29 \%$ & $13.86 \%$ & $14.84 \%$ & $13.61 \%$ & $14.57 \%$ & $16.30 \%$ & $13.64 \%$ & $20.79 \%$ & $21.08 \%$ & $19.34 \%$ \\
\hline $\mathrm{F}$ & 30,66 & 32,77 & 16,41 & 84,53 & 91,55 & 82,73 & 63,63 & 72,69 & 58,93 & 110,25 & 112,16 & 100,73 \\
\hline
\end{tabular}

Notes: $*, * *, * *$ significance levels at the $10 \%, 5 \%$ and $1 \%$.

\subsection{Impact of Voting Rights on Dividends Yield Ratios}

The results of measuring of the impact of voting rights on the first two measures of dividends yield ratios are presented in Table 5 (Gugler, 2003). The overall significance test indicates that the models are overall statistically significant. Our results show that the coefficient of the variable "leverage" has the expected negative sign and is significant at the $1 \%$ level in both models "PAYOUT1" and "PAYOUT2" for all specifications (Kevin Heibattollah and Zhou, 2012). Unlike the results of Fama and French (2001), we find that the impact of size on dividends is positive, meaning that larger firms assume less bankruptcy costs, and are therefore, more likely to distribute the highest amounts of dividends. The coefficient on firm size is statistically significant at the $1 \%$ level in both models of dividends.

Moreover, the "Market To Book" ratio negatively and significantly affects the dividend payout ratio at the $10 \%$ and 1\% levels, except for the "PAYOUT 1.6" specification (Hiulam, Ferdinand and Yao, 2001; Kevin, Heibattollah and Zhou, 2012). This result indicates that, contrary to the result found by Porta, Lopez, Shleifer and Vishny (2000), French firms prefer to retain liquidity instead of distributing dividends to finance their investment projects.

The coefficient on the lagged dividend yield variable is positive and statistically significant at the $1 \%$ level for "PAYOUT1.2" and "PAYOUT2.2" specifications (Fama and Babiak, 1968; Dickens, Casey and Newman, 2003). This result suggests that historical dividends play a major role in explaining the current dividends. In addition, the inclusion of this lagged variable does not change the significance or the sign of the other variables.

The results of the effect of the ownership structure are presented in Table 5 and indicate that the voting rights of the controlling shareholder, "Voting-Rights1", positively and significantly influence dividend payout ratio at the $10 \%$ level, only for the "PAYOUT2.1" specification. This result does not confirm the hypothesis of wealth expropriation of minority shareholders by the controlling shareholders and the result found by Faccio and Lang (2002). Similarly, the largest shareholder manager, the first institutional shareholder, positively and significantly affects dividend payout ratios for "PAYOUT1.4" and "PAYOUT2.5" specifications. Regarding the monitoring power as measured by "Cubbin and Leech" (1983) index, we found a positive and statistically significant effect on dividend yield ratio, only for the "PAYOUT1.6" specification. All these results enable us to reject the third hypothesis.

The estimation results of dividends yield ratios "PAYOUT3" and "PAYOUT4" are presented in Table 6. For the control variables, firm size has a positive and significant effect only for the first model, PAYOUT3", while 
growth opportunities has a negative and significant effect only for the second model, "PAYOUT 4" (La porta and al, 2000). Concerning the ownership structure variables, we found a positive and statistically significant effect at the $10 \%$ level of the largest shareholder manager on dividend policy, "PAYOUT 3.4". This result also rejects our research hypothesis and suggests that the first shareholder manager adopts an entrenchment behavior and prefers to retain profits rather than distribute them in the form of dividends. This behavior may cause a problem of overinvestment. The coefficients of the lagged variables are positive and statistically significant at the $1 \%$ level ("PAYOUT3.2" and "PAYOUT4.2"). Furthermore, the addition of these variables does not change the above conclusions.

Table 5. Impact of degree of control on dividends yield ratios

\begin{tabular}{|c|c|c|c|c|c|c|c|c|c|c|c|c|}
\hline & \multicolumn{6}{|c|}{ PAYOUT 1} & \multicolumn{6}{|l|}{ PAYOUT2 } \\
\hline & PAYOUT & PAYOUT & PAYOUT & PAYOUT & PAYOUT & PAYOUT & PAYOUT & PAYOUT & PAYOUT & PAYOUT & PAYOUT & PAYOUT \\
\hline & 1.1 & 1.2 & 1.3 & 1.4 & 1.5 & 1.6 & 2.1 & 2.2 & 2.3 & 2.4 & 2.5 & 2.6 \\
\hline $\mathrm{C}$ & $-0,671^{* * *}$ & $-0.455^{* * *}$ & $-0,761^{* * *}$ & $-0,796^{* * *}$ & $-0,717^{* * *}$ & $-0,836^{* * *}$ & $-0,104^{* * *}$ & -0.679604 & $-0,1105^{* * *}$ & $-0,103^{* * *}$ & $-0,0997^{* * *}$ & $-0,110^{* * *}$ \\
\hline SIZE & $0,0417^{* * *}$ & $0.0266^{* * *}$ & $0,0451^{* * *}$ & $0,0480^{* * *}$ & $0,0445^{* * *}$ & $0,0453^{* * *}$ & $0,00610^{* * *}$ & $0.003789^{* * *}$ & $0,00634^{* * *}$ & $0,00628^{* * *}$ & $0,00577^{* * *}$ & $0,00618^{* * *}$ \\
\hline Leverage & $-0,125^{* * *}$ & $-0.104^{* * *}$ & $-0,133^{* * *}$ & $-0,158^{* * *}$ & $-0,137^{* * *}$ & $-0,111^{* *}$ & $-0,0155^{* *}$ & $-0.0141^{* * *}$ & $-0,0159^{* * *}$ & $-0,0174^{* * *}$ & $-0,0163^{* * *}$ & $-0,0134^{*}$ \\
\hline МТВ & $-0,0041^{*}$ & $-0.006^{* * *}$ & $-0,0041^{*}$ & $-0,0041^{*}$ & $-0,0040^{*}$ & $-0,00415$ & $-0,0017^{* * *}$ & $-0.00052^{* *}$ & $-0,0017^{* * *}$ & $-0,0017^{* * *}$ & $-0,0017^{* * *}$ & $-0,0019^{* * *}$ \\
\hline VOT RIG1 & 0,0155 & -0.00131 & & & & & $0,0102^{*}$ & 0.0034504 & & & & \\
\hline Voting-Rights & & & 0,0429 & & & & & & 0,00774 & & & \\
\hline \multicolumn{13}{|l|}{ All } \\
\hline DDVIO1 & & & & $0,114^{* *}$ & & & & & & 0,00458 & & \\
\hline DDVOC1 & & & & & 0,0128 & & & & & & $0,0182^{* * *}$ & \\
\hline ALFA & & & & & & $0,100^{*}$ & & & & & & 0,00900 \\
\hline PAY (t-1) & & $0.564^{* * *}$ & & & & & & $0.602^{* * *}$ & & & & \\
\hline LOG LIKE & $-527,404$ & -329.729 & $-527,812$ & $-476,667$ & $-543,426$ & $-455,025$ & 2598,609 & 2889.0792 & 25967,405 & 2347,781 & 2693,841 & 1964,0601 \\
\hline CHI DEUX & 43,5 & 381.58 & 49,81 & 53,3 & 48,18 & 44,93 & 97,57 & 685.99 & 94,47 & 86,64 & 109,41 & 78,89 \\
\hline
\end{tabular}

Notes: $*, * *, * * *$ : significance levels at the $10 \%, 5 \%$ and $1 \%$.

Table 6. Impact of degree of control on dividend yield

\begin{tabular}{|c|c|c|c|c|c|c|c|c|c|c|c|c|}
\hline & \multicolumn{6}{|l|}{ PAYOUT 3} & \multicolumn{6}{|c|}{ PAYOUT 4} \\
\hline & PAYOUT & PAYOUT & PAYOUT & PAYOUT & PAYOUT & PAYOUT & PAYOUT & PAYOUT & PAYOUT & PAYOUT & PAYOUT & PAYOUT \\
\hline & 3.1 & 3.2 & 3.3 & 3.4 & 3.5 & 3.6 & 4.1 & 4.2 & 4.3 & 4.4 & 4.5 & 4.6 \\
\hline $\mathrm{C}$ & $-0,762^{* * *}$ & $-0.649^{* * *}$ & $-0,874^{* * *}$ & $-0,901^{* * *}$ & $-0,822^{* * *}$ & $-0,812^{* * *}$ & 0,0144 & $-0.0807^{* * *}$ & 0,0122 & 0,00721 & 0,0193 & $-0,00025$ \\
\hline Size & $0,0488^{* * *}$ & $0.0404^{* * *}$ & $0,0494^{* * *}$ & $0,0551^{* * *}$ & $0,0535^{* * *}$ & $0,0504^{* * *}$ & 0,000334 & $0.00451^{* * *}$ & 0,000544 & 0,000900 & 0,000242 & 0,000763 \\
\hline Leverage & $-0,248^{* * *}$ & $-0.202^{* * *}$ & $-0,247^{* * *}$ & $-0,285^{* * *}$ & $-0,268^{* * *}$ & $-0,291^{* * *}$ & $-0,032^{* * *}$ & $-0.0187^{* * *}$ & $-0,032^{* * *}$ & $-0,026^{* * *}$ & $-0,037^{* * *}$ & $-0,033^{* * *}$ \\
\hline МТВ & $-0,00309$ & -0.00326 & $-0,00311$ & $-0,00170$ & $-0,00337$ & $-0,00173$ & $-0,001^{* * *}$ & $-0.0014^{* * *}$ & $-0,001^{* * *}$ & $-0,001^{* * *}$ & $-0,0113^{* *}$ & $-0,001^{* * *}$ \\
\hline VOT RIG1 & 0,00284 & 0.0133 & & & & & 0,00973 & 0.00314 & & & & \\
\hline Voting-Rights All & & & 0,1069 & & & & & & 0,00299 & & & \\
\hline DDVIO1 & & & & $0,0842^{*}$ & & & & & & $-0,00745$ & & \\
\hline DDVOC1 & & & & & $-0,0341$ & & & & & & 0,00258 & \\
\hline ALFA & & & & & & 0,0365 & & & & & & 0,106 \\
\hline PAY (t-1) & & $0.2531^{* * *}$ & & & & & & $0.565^{* * *}$ & & & & \\
\hline LOG LIKE & $-675,144$ & -632.390 & $-674,448$ & $-607,766$ & $-710,470$ & $-563,710$ & 2184,285 & 2435.492 & 2183,229 & 2073,145 & 2140,542 & 1598,426 \\
\hline CHI DEUX & 63,98 & 168.48 & 60,44 & 69,97 & 74,58 & 62,1 & 37,52 & 1060.98 & 35,27 & 29,93 & 24,74 & 29,31 \\
\hline
\end{tabular}

Notes: ${ }^{*},{ }^{* *},{ }^{* * *}$ significance levels at the $10 \%, 5 \%$ and $1 \%$.

\subsection{Impact of Voting Rights of Other Shareholders}

In what follows, we test the impact of monitoring power of the second shareholder, and other shareholders other than the largest shareholder, using the two dummy variables defined above (Classens and al, 2000; La porta and al, 200). The results of the first two dividends yield ratios are presented in Table 7. 
Only the second model, the coefficient of the variable "2-large-shareholder" is negative and significant at the $10 \%$ level ("PAYOUT2.2" et "PAYOUT 2.3"). This result means that the second largest shareholder of French firms affects negatively the dividend policy. In contrast, the results indicate that shareholders of French firms other than the largest shareholder does not influence distributed dividends. However, in a dynamic framework we found a positive and statistically significant effect at the $1 \%$ level between dividend yield and lagged variable ("PAYOUT1.3" and "PAYOUT 2.3"). The only difference found for the other variables is that the effect of the voting rights of the controlling shareholder is not statistically significant for the "PAYOUT 2.3" specification.

The estimation results for the other two dividends yield ratios are presented in Table 8 . They indicate that the second largest shareholder and other shareholders other than the largest shareholder have no influence on dividend yield ratios measured by "PAYOUT 3" and "PAYOUT 4". Consistent with the results of the previous section, our empirical findings remain unchanged in a dynamic context since adding the lagged variable does not change neither the signs nor the significance of the other variables.

\section{Why Firms Distribute Dividends}

Similar to the work of David and Osobov (2008), we study why firms distribute dividends? Therefore, the results of the test to identify and determine the decision to distribute dividends are presented in Table 9. The results show that the Wald Chi 2 test indicates that all specifications are generally statistically significant. The independents variables explain about a maximum of $28.69 \%$ of decision policy ("DIVPAY5"). The decision to distribute dividends is negatively affected by "leverage" and positively affected by the "size" of the firm with the two estimated coefficients are significant in all specifications at the $10 \%$ and $1 \%$ levels respectively. The coefficient of the ratio "MTB" is negative and statistically significant at the $1 \%$ level.

The results indicate that the estimated coefficient of the variable "voting rights of the controlling shareholder", is positive and statistically significant at the $1 \%$ level for all specifications ("DIVPAY1", "DIVPAY5" and "DIVPAY6") contrary to what is expected. This means that the largest shareholder encourages managers to distribute more dividends. In contrast, the second largest shareholder acts to the detriment of managers, since the coefficient of the variable "2-large-shareholder" is negative and statistically significant "DIVPAY5". However, shareholders of French firms other than the largest shareholder, does not affect significantly the dividend policy "DIVPAY7".

The estimation results of the interaction effect between net earnings and ownership structure on dividend policy are presented in Table 10. The empirical results show that the effect of the variable "NLOSS" is negative and statistically significant at $1 \%$ level on the dividend policy for all specifications. In fact, deficit earnings issue a bad signal to external investors (Bhattacharay, 1979; Miller and Rock, 1985). However, the effects of the interaction terms for specifications "DIVINT1", "DIVINT2", "DIVINT5" and "DIVINT6" are negative and insignificant and mitigate the negative effect of the variable "NLOSS" interaction terms for specifications "DIVINT3" and "DIVINT4" are positive and insignificant and partially offset the negative effect of the earnings deficit on the dividend distribution. This result is explained by the fact that firms with a dispersed ownership structure distribute more dividends than firms with a concentrated ownership structure. In addition, it should be noted that the above conclusions regarding the effect of size, leverage and Market To Book ratios on dividend policy still remain.

Table 7. Impact of degree of control of other shareholders on dividends yield ratios

\begin{tabular}{|c|c|c|c|c|c|c|c|c|c|c|}
\hline & \multicolumn{5}{|c|}{ PAYOUT 1} & \multicolumn{5}{|l|}{ PAYOUT 2} \\
\hline & PAYOUT & PAYOUT & PAYOUT & PAYOUT & PAYOUT & PAYOUT & PAYOUT & PAYOUT & PAYOUT & PAYOUT \\
\hline & 1.1 & 1.2 & 1.3 & 1.4 & 1.5 & 2.1 & 2.2 & 2.3 & 2.4 & 2.5 \\
\hline $\mathrm{C}$ & $-0,670^{* * *}$ & $-0,775^{* * *}$ & $-0.452^{* * *}$ & $-0,760^{* * *}$ & $-0.760^{* * *}$ & $-0,104^{* * *}$ & $-0,0912^{* * *}$ & $-0.0560^{* * *}$ & $-0,107^{* * *}$ & $0.110^{* * *}$ \\
\hline Size & $0,0417^{* * *}$ & $0,0427^{* * *}$ & $0.0266^{* * *}$ & $0,0434^{* * *}$ & $0.0450^{* * *}$ & $0,00610^{* * *}$ & $0,00608^{* * *}$ & $0.00374^{* * *}$ & $0,00612^{* * *}$ & $0.00633^{* * *}$ \\
\hline Leverage & $-0,125^{* * *}$ & $-0,125^{* * *}$ & $-0.103^{* * *}$ & $-0,125^{* * *}$ & $-0.133^{* * *}$ & $-0,0155^{* *}$ & $-0,0156^{* *}$ & $-0.0141^{* * *}$ & $-0,0155^{* *}$ & $-0.0159^{* * *}$ \\
\hline MTB & $-0,00416^{*}$ & $-0,00425^{*}$ & $-0.00695^{* * *}$ & $-0,00420^{*}$ & $-0.00415^{*}$ & $-0,00171^{* * *}$ & $-0,00170^{* * *}$ & $-0.00050^{* *}$ & $-0,00171^{* * *}$ & $-0.00174^{* * *}$ \\
\hline VOT RIG1 & 0,0155 & 0,0251 & -0.00179 & 0,0295 & & $0,0102^{*}$ & $0,00872^{*}$ & 0.00218 & $0,0107^{*}$ & \\
\hline 2 LAR SH & & 0,0862 & -0.00297 & & & & $-0,0120^{*}$ & $-0.0105^{*}$ & & \\
\hline OTHER L & & & & 0,0558 & & & & & 0,00212 & \\
\hline Voting-Rights All & & & & & 0.0429 & & & & & 0.00774 \\
\hline PAY (t-1) & & & $0.563^{* * *}$ & & & & & $0.601^{* * *}$ & & \\
\hline LOG LIKE & $-527,404$ & $-526,490$ & -329.692 & $-526,768$ & -527.812 & 2598,609 & 2600,493 & 2890.592 & 2599,169 & 2597.404 \\
\hline CHI DEUX & 43,5 & 46,39 & 379.99 & 46,78 & 49.81 & 97,57 & 100,58 & 688.09 & 97,8 & 94.47 \\
\hline
\end{tabular}

Notes: ${ }^{*},{ }^{*},{ }^{* *}$ significance levels at the $10 \%, 5 \%$ and $1 \%$. 
Table 8. Impact of degree of control of other shareholders on dividends yield ratios

\begin{tabular}{|c|c|c|c|c|c|c|c|c|c|c|}
\hline & \multicolumn{5}{|c|}{ PAYOUT 3} & \multicolumn{5}{|l|}{ PAYOUT 4} \\
\hline & PAYOUT & PAYOUT & PAYOUT & PAYOUT & PAYOUT & PAYOUT & PAYOUT & PAYOUT & PAYOUT & PAYOUT \\
\hline & 3.1 & 3.2 & 3.3 & 3.4 & 3.5 & 4.1 & 4.2 & 4.3 & 4.4 & 4.5 \\
\hline$\overline{\mathrm{C}}$ & $-0,762^{* * *}$ & $-0,818^{* * *}$ & $-0.679^{* * *}$ & $-0,839^{* * *}$ & $-0.874^{* * *}$ & 0,0144 & 0,0280 & $-0.0696^{* * *}$ & 0,00662 & 0.0122 \\
\hline Size & $0,0488^{* * *}$ & $0,0493^{* * *}$ & $0.0406^{* * *}$ & $0,0492^{* * *}$ & $0.0494^{* * *}$ & 0,000334 & 0,000302 & $0.00446^{* * *}$ & 0,000351 & 0.000544 \\
\hline Leverage & $-0,248^{* * *}$ & $-0,248^{* * *}$ & $-0.201^{* * *}$ & $-0,241^{* * *}$ & $-0.247^{* * *}$ & $-0,0325^{* * *}$ & $-0,0323^{* * *}$ & $-0.0187^{* * *}$ & $-0,0321^{* * *}$ & $-0.0327^{* * *}$ \\
\hline МТВ & $-0,00309$ & $-0,00318$ & -0.00325 & $-0,00321$ & -0.00311 & $-0,00171^{* * *}$ & $-0,0016^{* * *}$ & $-0.00144^{* * *}$ & $-0,0017^{* * *}$ & $-0.0017^{* * *}$ \\
\hline VOT RIG1 & 0,00284 & 0,00944 & 0.0170 & 0,0190 & & 0,00973 & 0,00844 & 0.00184 & 0,0115 & \\
\hline 2 LAR SH & & 0,0461 & 0.0259708 & & & & $-0,0133$ & -0.00947 & & \\
\hline OTHER L & & & & $0,0548(1)$ & & & & & 0,00576 & \\
\hline VRALL & & & & & 0.106 & & & & & 0.00299 \\
\hline PAY (t-1) & & & $0.252^{* * *}$ & & & & & $0.565^{* * *}$ & & \\
\hline LOG LIKE & $-675,144$ & $-674,623$ & -632.273 & $-674,538$ & -674.448 & 2184,285 & 2185,0584 & 2436.0431 & 2184,398 & 2183.229 \\
\hline CHI DEUX & 63,980 & 65,360 & 168.840 & 66,990 & 60.440 & 37,520 & 38,940 & 1069.310 & 37,570 & 35.270 \\
\hline
\end{tabular}

Notes: ${ }^{* * *}{ }^{* * *}$ significance levels at the $10 \%, 5 \%$ and $1 \%$.

Table 9. Determinants of the dividends distribution decision

\begin{tabular}{|c|c|c|c|c|c|c|c|}
\hline & DIVPAYER & & & & & & \\
\hline & DIVPAY1 & DIVPAY2 & DIVPAY3 & DIVPAY4 & DIVPAY5 & DIVPAY6 & DIVPAY7 \\
\hline $\bar{C}$ & $-9,307^{* * *}$ & $-9,517^{* * *}$ & $-8,981^{* * *}$ & $-11,618^{* * *}$ & $-7,832^{* * *}$ & $-9,764^{* * *}$ & $-9,411^{* * *}$ \\
\hline Size & $0,483^{* * *}$ & $0,518^{* * *}$ & $0,502^{* * *}$ & $0,555^{* * *}$ & $0,483^{* * *}$ & $0,485^{* * *}$ & $0,498^{* * *}$ \\
\hline Leverage & $-0,700^{*}$ & $-0,953^{* *}$ & $-0,870^{* *}$ & $-0,348$ & $-0,716^{*}$ & $-0,696^{*}$ & $-0,765^{*}$ \\
\hline MTB & $-0,218^{* * *}$ & $-0,205^{* * *}$ & $-0,220^{* * *}$ & $-0,227^{* * *}$ & $-0,221^{* * *}$ & $-0,218^{* * *}$ & $-0,220^{* * *}$ \\
\hline VOT RIG1 & $1,00411^{* * *}$ & & & & $0,840^{* *}$ & $1,0979^{* * *}$ & \\
\hline DDVIO1 & & 0,502 & & & & & \\
\hline DDVOC1 & & & $-0,135$ & & & & \\
\hline ALFA & & & & $1,240^{* * *}$ & & & \\
\hline $2 \mathrm{LAR} \mathrm{SH}$ & & & & & $-1,406^{* *}$ & & \\
\hline OTHER L & & & & & & 0,365 & \\
\hline VRALL & & & & & & & 0,408 \\
\hline $\mathrm{R}^{2}$ & $28.025 \%$ & $26.50 \%$ & $27.14 \%$ & $34.59 \%$ & $28.69 \%$ & $28.04 \%$ & $27.23 \%$ \\
\hline LOG LIK & $-1198,164$ & $-1093,208$ & $-1242,252$ & $-944,769$ & $-1194,901$ & $-1197,798$ & $-1202,353$ \\
\hline CHI DEUX & 127,47 & 117,95 & 127,56 & 102,05 & 127,74 & 127,99 & 123,19 \\
\hline
\end{tabular}

Notes: ${ }^{* * *}{ }^{* * * *}$ significance levels at the $10 \%, 5 \%$ and $1 \%$.

Table 10. Effect of interaction of earnings loss and ownership structure on dividend decision

\begin{tabular}{|c|c|c|c|c|c|c|}
\hline & \multicolumn{6}{|c|}{ DIVPAYERS } \\
\hline & DIVINT1 & DIVINT2 & DIVINT3 & DIVINT4 & DIVINT5 & DIVINT6 \\
\hline $\mathrm{C}$ & $-8,212^{* * *}$ & $-8,210^{* * *}$ & $-8,197^{* * *}$ & $-8,171^{* * *}$ & $-8,212^{* * *}$ & $-8,210^{* * *}$ \\
\hline Size & $0,464^{* * *}$ & $0,464^{* * *}$ & $0,464^{* * *}$ & $0,463^{* * *}$ & $0,464^{* * *}$ & $0,464^{* * *}$ \\
\hline Leverage & $-0,836^{* *}$ & $-0,843^{* *}$ & $-0,847^{* *}$ & $-0,853^{* *}$ & $-0,836^{* *}$ & $-0,843^{* *}$ \\
\hline МТВ & $-0,218^{* * *}$ & $-0,218^{* * *}$ & $-0,218681^{* * *}$ & $-0,218^{* * *}$ & $-0,218^{* * *}$ & $-0,218^{* * *}$ \\
\hline $\operatorname{NLOSS}_{\mathrm{t}}$ & $-0,679^{* * *}$ & $-0,654^{* * *}$ & $-0,754^{* * *}$ & $-0,989^{* *}$ & $-0,679^{* * *}$ & $-0,654^{* * *}$ \\
\hline $\mathrm{EBO1}_{\mathrm{i}, \mathrm{t}-1} * \mathrm{NLOSS}_{\mathrm{t}}$ & $-0,703$ & & & & & \\
\hline $\mathrm{EBO}_{\mathrm{i}, \mathrm{t}-\mathrm{1}} * \mathrm{NLOSS}_{\mathrm{t}}$ & & $-0,152$ & & & & \\
\hline $\mathrm{IO1}_{\mathrm{i}, \mathrm{t}-1} * \mathrm{NLOSS}_{\mathrm{t}}$ & & & 0,05126 & & & \\
\hline $\mathrm{IO} 2_{\mathrm{i}, \mathrm{t}-1} * \mathrm{NLOSS}_{\mathrm{t}}$ & & & & 0,327 & & \\
\hline OW1 $1_{\mathrm{i}, \mathrm{t}-1} * \mathrm{NLOSS}_{\mathrm{t}}$ & & & & & $-0,703$ & \\
\hline OW2 $2_{\mathrm{i}, \mathrm{t}-1} * \mathrm{NLOSS}_{\mathrm{t}}$ & & & & & & $-0,152$ \\
\hline $\mathrm{R}^{2}$ & $23.94 \%$ & $24.03 \%$ & $24.017 \%$ & $24.12 \%$ & $23.94 \%$ & $24.037 \%$ \\
\hline LOG LIK & $-1234,749$ & $-1235,0928$ & $-1235,180$ & $-1234,932$ & $-1234,749$ & $-1235,0928$ \\
\hline CHI DEUX & 145,25 & 144,64 & 144,49 & 144,01 & 145,25 & 144,64 \\
\hline
\end{tabular}

Notes: ${ }^{*},{ }^{* *},{ }^{* * *}$ : significance levels at the $10 \%, 5 \%$ and $1 \%$. 


\section{Conclusion}

The dividend policy remains a central problem in financial theory. In this regard, the aim of this paper is to test the relationship between dividend policy and ownership structure. We emphasized, as in this article, the effect of expropriation of minority shareholder wealth by testing the impact of voting rights of shareholders on dividend yield ratios. In this article, the results of the four partial adjustment models reject the hypothesis of a positive relationship between dividends and institutional shareholders. However, the separation between ownership and control leads us to examine the relationship between the shareholders' voting rights and dividend policy. The results of "TOBIT" regressions point to a positive and significant impact of the voting rights of the controlling shareholder on dividend ratios and do not confirm our hypothesis of expropriation of minority shareholder wealth. These results remain unchanged in a dynamic framework. The sensitivity analysis of our results indicates that the effect of expropriation of wealth is only valid for the second largest shareholder. Similarly, we extend our analysis to test the effect of the interaction between ownership structure and firm earnings on dividend policy. The results show that the ownership structure mitigates the negative effect of the variable "NLOSS," on dividend policy.

\section{References}

Amitabh, \& Fairleigh. (1999). Managerial Ownership, Dividend and Debt Policy in The US Banking Industry. Managerial Finance, 25(6), 57. http://dx.doi.org/10.1108/03074359910766019

Barclay, M. J., Smith, C. W., \& Watts, R. L. (1995). the determinants of corporate leverage and dividend policies. Journal of Applied Corporate Finance, Winter, 4-19. http://dx.doi.org/10.1111/j.1745-6622.1995.tb00259.x

Bathala, \& Rao. (1994). Managerial Ownership, Debt Policy, and The Impact of Institutional Holdings: an Agency Perspective. Financial Management, 23, 38-50. http://dx.doi.org/10.2307/3665620

Benartzi, S., Michaely, R., \& Thaler, R. (1997). Do changes in dividends signal the future or the past? Journal of Finance, 52, 1007-1034. http://dx.doi.org/10.1111/j.1540-6261.1997.tb02723.x

Bhagat, S., \& Jefferis Jr., R. H. (2002). The Econometrics of Corporate Governance Studies. Cambridge, Massachusetts: the MIT Press.

Bhattacharay, S. (1979). Nondissipative Signalling Structures and Dividend Policy. the Quaterly Journal of Economics, 95(1), 1-24.

Bohren, Y., Josefen, M., \& Steen, P. (2012). stakeholder conflicts and dividend policy. L OF Banking and Finance, 36(10), 2852-2864.

Bradley, M., Jarell, G., \& Kim, E. H. (1984). on the existence of an optimal capital structure: theory and evidence. Journal of Finance, 39, 857-878.

Brav, A., Graham, J., Harvey, C., \& Michaely, R. (2005). payout policy in the $21^{\text {st }}$ century. Journal of Financial Economics, 77, 483-527. http://dx.doi.org/10.1016/j.jfineco.2004.07.004

Chen, C., \& Steiner, L. (1999). Managerial Ownership and Agency Conflicts: A Nonlinear Simultaneous Equation Analysis of Managerial Ownership, Risk Taking, Debt Policy, and Dividend Policy. The Financial Review, 34, 119-136. http://dx.doi.org/10.1111/j.1540-6288.1999.tb00448.x

Chenn, D., Jian, M., \& Xu, M. (2009). dividends for tunnelling in a regulated economy: the case of China. Pacific Basin Finance Journal, 17, 209-223. http://dx.doi.org/10.1016/j.pacfin.2008.05.002

Christian, A., André, B., Marc, G., \& Renneboog, L. (2011). Dividend policy of German firms A panel data analysis of partial adjustment models. Journal of Empirical Finance, 16, 175-187.

Classens, S., Djankov, S., \& Lang, L. H. P. (2000). the separation of ownership and control in East Asian corporations. Journal of Fial Economics, 58, 81-112.

Crutchley, C., \& Hansen, R. (1989). A Test of the Agency Theory of Managerial Ownership, Corporate Leverage and Corporate Dividends. Financial Management, 18(4), 36-46. http://dx.doi.org/10.2307/3665795

Crutchley, C., \& Raymond. (1999). Agency Problems and the Simultaneity of Financial Decision Making: The Role of Institutional Ownership. International Review of Financial Analysis, 8(2).

Darren, H. (2011). Ownership structure and tax-friendly dividends. Journal of Banking and Finance, 35, 2747-2760. http://dx.doi.org/10.1016/j.jbankfin.2011.03.003

David, J., \& Osobov, I. (2008). Why do firms pay dividends? International evidence on the determinants of dividend policy. Journal of Financial Economics, 89, 62-82. http://dx.doi.org/10.1016/j.jfineco.2007.06.006 
DeAngelo, H., DeAngelo, L., \& Stulz, R. M. (2004). Dividend policy, agency costs, and earned equity. Working Paper, University of Southern California.

Denis, D. J., \& Osobov, I. V. (2007). Why do firms pay dividends? International evidence on the determinants of dividend policy. Working Paper, Purdue University.

Dewenter, K., \& Warther, V. (1998). Dividends, asymmetric information, and agency conflicts: Evidence from a comparison of the dividend policies of Japanese and U.S. firms. Journal of Finance, 53, 879-904. http://dx.doi.org/10.1111/0022-1082.00038

Dickens, C., \& Newman. (2003). Bank Dividend Policy: Explanatory Factors. Quarterly Journal of Business and Economics, 41(2).

Dittmann, I., \& Maug, E. G. (2007). Lower salaries and no options: The optimal structure of executive pay. Journal of Finance, 62, 303-343. http://dx.doi.org/10.1111/j.1540-6261.2007.01208.x

Du, J., \& Dai, Y. (2004). Ultimate corporate ownership structure and capital structure: Evidence from East Asia. Working paper N 13. Hong Kong: Chinese University of Hong Kong.

Easterbrook, F. H. (1984). Two Agency Cost Explanations of Dividends. the American Economic Review, 74(4), 250-259.

Eckbo, B. E., \& Verma, S. (1994). managerial shareownership, voting power and cash dividend policy. Journal of Corporate Finance, 1, 33-62. http://dx.doi.org/10.1016/0929-1199(94)90009-4

Faccio, M., \& Lang. (2002). The ultimate ownership of Western European corporations. Journal of Financial Economics, 65, 365-395. http://dx.doi.org/10.1016/S0304-405X(02)00146-0

Faccio, M., Lang, L. H. P., \& Young, L. (2001). dividend and expropriation. American Economic Review, 91(1), 54-78. http://dx.doi.org/10.1257/aer.91.1.54

Fama, \& Harvey, B. (1968). Dividend Policy: An Empirical Analysis. The Journal of The American Statistical Association, 63(324), 1132-1161. http://dx.doi.org/10.1080/01621459.1968.10480917

Fama, E., \& French, K. (2001). Disappearing dividends: Changing firm characteristics or lower propensity to pay? Journal of Financial Economics, 60, 3-43. http://dx.doi.org/10.1016/S0304-405X(01)00038-1

Glen, J., Karmokolias, Y., Miller, R., \& Shah, S. (1995). Dividend policy and behavior in emerging markets: To pay or not to pay. IFC Discussion Paper No. 26.

Goergen, R., \& Silva. (2005). When Do German Firms Change Their Dividends? Journal of Corporate Finance, 11, 375-399. http://dx.doi.org/10.1016/j.jcorpfin.2003.09.001

Goshen, Z. (1995). Shareholder dividend options. The Yale Law Journal, 104, 881-932. http://dx.doi.org/10.2307/797108

Gugler, K. (2003). Corporate Governance and Dividend Payout Policy in Germany. European Economic Review, 47, 731-758. http://dx.doi.org/10.1016/S0014-2921(02)00291-X

Hart, O. (1995). Firms, Contracts and Capital Structure. Oxford, U.K.: Oxford University Press. http://dx.doi.org/10.1093/0198288816.001.0001

Hart, O., \& Moore, J. (1994). A theory of debt based on the inalienability of human capital. NBER Working paper.

Hiulam, C., Ferdinand, A., \& Yao, J. (2011). does political economiy reduce agency costs? Some evidence from dividend policies around the world. Journal of Empirical Finance, 18(1), 16-35. http://dx.doi.org/10.1016/j.jempfin.2010.10.001

Holderness, C. G. (2003). a survey of blockholders and corporate control. Economic Policy Review, 9(1), 51-64.

Holderness, C., \& Sheehan, D. (2000). Constraints on Large-Block Shareholders. In Randall A. Morck (Ed.), Concentrated Corporate Ownership (National Bureau of Economic Research). Chicago, IL: University of Chicago Press.

Jalilvand, \& Harris, R. (1984). Corporate Behaviour In Adjusting To Capital Structure And Dividend Targets: An Econometric Study. Journal Of Finance, 49(1), 127-145.

Jensen, \& Meckling. (1976). Theory of The Firm: Managerial Behaviour, Agency Costs And Ownership Structure. Journal of Financial Economics, 3(4).

Jensen, \& Thomas. (1992). Simultaneous Determination of Insider Ownership, Debt, And Dividend Policies. 
Journal of Financial and Quantitative Analysis, 247-263.

Jensen, M. C. (1986). Agency Costs of Free Cash Flow, Corporate Finance and Takeovers. The American Economic Review, 76(2), 323-329.

Jensen, S., \& Zorn. (1992). Simultaneous Determination Of Insider Ownership, Debt And Dividend Policies. Journal of Financial and Quantitative Analysis, 27(2). http://dx.doi.org/10.2307/2331370

Johnson, S., La Porta, R., Lopez-De-Silanes, F., \& Shleifer, A. (2000). Tunnelling. American Economic Review, Papers and Proceedings, 90, 22-27. http://dx.doi.org/10.1257/aer.90.2.22

Jouahn, N., Wang, J., \& Zhang, G. (2010). The impact of the dividend tax cut and managerial stock holdings on corporate dividend policy. Global Finance Journal, 21, 275-292. http://dx.doi.org/10.1016/j.gfj.2010.09.005

Kevin, C. K., Heibatollah, S., \& Zhou. (2012). the role of cross listing, foreign ownership and state ownership in dividend policy in an emerging market. China Journal of Accounting Research, 5, 199-216.

Khan, T. (2006). Company Dividends and Ownership Structure: Evidence From UK Panel Data. The Economic Journal, 116, 172-189. http://dx.doi.org/10.1111/j.1468-0297.2006.01082.x

Kim, H. L. (2010). Firm value, growth, profitability and capital structure of listed real estate companies: an international perspective. Journal of Property Research, 27(2), 119-146. http://dx.doi.org/10.1080/09599916.2010.500459

Kimie, H., \& Pascal, N. (2011). Ownership concentration and dividend policy in Japan. Managerial Finance, $37(4)$.

La Porta, R., Lopez-de-Silanes, F., Shleifer, A., \& Vishny, R. (2000). Agency problems and dividend policies around the world. Journal of Finance, 55, 1-33. http://dx.doi.org/10.1111/0022-1082.00199

Leithner, S., \& Zimmermann, H. (1993). Market value and aggregate dividends: A reappraisal of recent tests, and evidence from European markets. Swiss Journal of Economics and Statistics, 129, 99-122.

Leland, H., \& Pyle, D. (1977). Information Asymmetrics, Financial Structure, and Financial Intermediation. Journal of Finance, 32, 371-388. http://dx.doi.org/10.2307/2326770

Lintner, J. (1956). Distribution of Incomes of Corporations among Dividends, Retained Earnings and Taxes. The American Economic Review, 46(2), 97-113.

Luciana, A. (2006). Ownership Structure and Dividend Policy: Evidence From Italian Firms. The European Journal Of Firms, 12(3), 265-282.

Mancinelli, L., \& Ozkan, A. (2006). ownership structure and dividend policy: evidence from Italian firms. European Journal of Finance, 12(3), 265-282. http://dx.doi.org/10.1080/13518470500249365

McDonald, J., Jacquillat, B., \& Nussenbaum, M. (1975). Dividend, investment and financing decisions: Empirical evidence on French firms. Journal of Financial and Quantitative Analysis, 10, 741-755. http://dx.doi.org/10.2307/2330268

Miller, M., \& Rock, K. (1985). Dividend Policy Under Asymmetric Information. The Journal Of Finance, 40(4), 1031-1051. http://dx.doi.org/10.1111/j.1540-6261.1985.tb02362.x

Mohd, P., \& Rimbey. (1995). The Impact of Ownership Structure on Corporate Debt Policy: A Time Series $\begin{array}{llll}\text { Cross-Sectional Analysis. The } & \text { Financial }\end{array}$ http://dx.doi.org/10.1111/j.1540-6288.1998.tb01384.x

Morck, R., Shleifer, A., \& Vishny, R. W. (1988). Management Ownership and Market Valuation: an Empirical Analysis. Journal of Financial Economics, 20, 293-315. http://dx.doi.org/10.1016/0304-405X(88)90048-7

Myers, S. (2000). Outside Equity. the Journal of Finance, 5(3), 1005-1037.

Ofer, A., \& Thakor, A. (1987). A theory of stock price responses to alternative corporate cash disbursement methods: Stock repurchases and dividends. Journal of Finance, 42, 889-911. http://dx.doi.org/10.1111/j.1540-6261.1987.tb03918.x

Partington, G. (1984). Dividend policy and target payout ratios. Journal of Accounting and Finance, 24, 63-74.

Peterdon, P. P., \& Benesh, G. A. (1983). a re-examination of the empirical relationship between investment and financing decisions. Journal of Financial and Quantitative Analysis, 18, 439-453. http://dx.doi.org/10.2307/2330939 
Robinson, J. (2006). Dividend policy among publicly listed firms in Barbados. Journal of Eastern Caribbean Studies, 31, 1-36.

Ross, N., Michael, C., \& Joseph, N. (2003). bank dividend policy: explanatory factors. Quarterly Journal of Bness and Economics, 41(1/2), 3.

Rozeff, M. (1982). Growth, Beta and Agency Costs as Determinants of Dividend Payout Ratios. The Journal of Financial Research, 5(3).

Schooley, D. K. \& Barney, L. (1994). Using Dividend Policy And Managerial Ownership To Reduce Agency Costs. Journal Of Financial Research, 17(3), 363-373.

Shevlin, T. (1982). Australian corporate dividend policy: Empirical analysis. Accounting and Finance, 22, 1-22. http://dx.doi.org/10.1111/j.1467-629X.1982.tb00127.x

Shleifer, A., \& Vishny, R. (1986). Large Shareholders and Corporate Control. Journal of Political Economy, 94(3), 461-488. http://dx.doi.org/10.1086/261385

Shleifer, A., \& Vishny, R. (1997). A survey of corporate governance. Journal of Finance, 52(2), 737-783.

Short, H., Zhang, H., \& Keasey, K. (2002). The Link Between Dividend Policy and Institutional Ownership. Journal of Corporate Finance, 8, 105-122. http://dx.doi.org/10.1016/S0929-1199(01)00030-X

Stulz, R. (1988). Managerial Control Of Voting Rights: Financing Policies and The Market For Corporate Control. Journal of Financial Economics, 20(1), 25-54. http://dx.doi.org/10.1016/0304-405X(88)90039-6

Szilagyi, P. G., \& Renneboog, L. (2007). how relevant is dividend policy under low shareholder protection? Working paper, University of Cambridge and Tilburg University.

Thomson, S. (2005). conflicts of interests or aligned incetives? Blockholder ownership, dividends and firm value in the US and the EU. European Business Organization Law Review, 6(2), 201-226. http://dx.doi.org/10.1017/S1566752905002016

Tom, V., \& Walter, A. (2011). Intra-industry conformity in dividend policy. Managerial Finance, 37(6).

Townsend, R. M. (1979). Optimal contracts and competitive markets with costly state verification. Journal of Economic Theory, 21, 265-293. http://dx.doi.org/10.1016/0022-0531(79)90031-0

Vineeta, S. (2011). Independent directors and the propensity to pay dividends. Journal of Corporate Finance, 17, 1001-1015. http://dx.doi.org/10.1016/j.jcorpfin.2011.05.003

Wang, X., David, M., \& Scott, W. (2011). The impact of government ownership on dividend policy in China. Advances in Accounting, incorporating Advances in International Accounting, article in Press

Zeckhauser, R. J., \& Pound, J. (1990). In Hubbard, R. G (Ed.), are large shareholders effective monitors? an investigation of share ownership and corporate performance (pp. 149-180). University of Chicago Press.

Zuoping, X. (2011). Ownership-control rights divergence, government intervention and choice of capital structure Empirical evidence from listed companies in China. Nankai Business Review International, 2(3).

\section{Copyrights}

Copyright for this article is retained by the author(s), with first publication rights granted to the journal.

This is an open-access article distributed under the terms and conditions of the Creative Commons Attribution license (http://creativecommons.org/licenses/by/3.0/). 